\title{
REVIEW
}

\section{Sarah Stroumsa}

\section{Maimonides in His World: Portrait of a Mediterranean Thinker}

Princeton, NJ: Princeton University Press, 2009, $x x+222$ pp.

Reviewed by Jason Kalman, Hebrew Union College - Jewish Institute of Religion

In 1997, Collette Sirat asked "Should We Stop Teaching Maimonides?" (in Raphael Jospe, ed., Paradigms in Jewish Philosophy, Madison: Fairleigh Dickinson University Press, 1997) and argued, against the vast majority of her colleagues, that we should. The appearance of two sixhundred page biographies of the great rabbi, doctor, and philosopher [Joel L. Kraemer, Maimonides: The Life and World of One of Civilization's Greatest Minds (New York: Doubleday, 2008) and, Herbert Davidson, Moses Maimonides: The Man and His Works (Oxford: Oxford University Press, 2004)], along with scores of other books and articles on various aspects of his biography and thought suggests that more than a decade later the resounding answer to Sirat's question remains a very clear "no." Given the popularity of Maimonides as a subject for contemporary scholarship the real question that needs to be asked is what aspects of the subject remain to be studied and by what methods should they be approached? In Maimonides in His World Sarah Stroumsa lays out her answer to these questions.

For Stroumsa, Maimonides is to be understood as a Mediterranean thinker. By this she means both that he, from the perspective of geography, lived his life around the Mediterannean basin and more importantly, was a cultural product of having lived among the intertwined groups who inhabited the region:

Maimonides' cultural Mediterranean encompassed the legacy of other religious communities. His world included the cultures of various communities in the Mediterranean basin of his days: Muslims, Jews, Christians, with their various denominations and sectarian disagreements. He was familiar with their philosophical and religious traditions, and with the mental world, the imaginaire, of both educated and simple people. His world also included past and extinct communities, previous layers of the Mediterranean palimpsest, whose imprints were left in Arabic literature. Maimonides fully lived and breathed the culture of his time, including the impact of contemporary culture, as well as sediments of previous cultures. (p. 13).

In exploring Maimonides from this perspective Stroumsa is not breaking new ground. By her own reckoning her goal is not to provide an overview of Maimonides's thought or to explore in depth one particular aspect of his thought. Nor does she attempt to describe Maimonides's role in a particular field (e.g., philosophy, science, law or medicine) or to contribute by adding to aspects of his biography. Stroumsa attempts to present what she describes as Maimonides's "cultural biography": his "interaction with his multi-faceted historical and cultural legacy, and how this cultural context affected him and shaped his thought" (p. xii). To this end, the book offers more of a collection of snapshots which might shape an intellectual and cultural biography but not the biography itself. In this regard Joel Kraemer's Maimonides: The Life and World of One of Civilization's Greatest Minds is similar in approach but a more thorough traditional biography. 
Chapter 1, "Maimonides and Mediterranean Culture," sets Maimonides in his historical and cultural context. It provides an overview of the cultural, religious, linguistic, and intellectual milieus in which Maimonides found himself as he moved from Cordoba to Fez to Palestine and finally to Fostat. In chapter 2, "The Theological Context of Maimonides' Thought," Stroumsa explores Maimonides's knowledge of Islamic thinkers. The chapter is significant in that Stroumsa expands the list of sources Maimonides drew from. He cites very few of sources-Jewish, Christian, or Muslim-and Stroumsa is committed to the fact that those scholars who are identified by name in his works were only a few of the thinkers with whose work Maimonides was familiar. Stroumsa's Maimonides was fully engaged with the world around him and, as such, likely read much of the material available to him whether he references it explicitly or not.

Chapter 3, "An Almohad 'Fundamentalist"' Explores the Influence of Almohad Thought and Theology on Maimonides." Maimonides lived under Almohad rule for close to two decades between 1148 and 1165 in Spain and North Africa. The major contribution of the chapter is highlighting the influence of Almohad legal methodology on Maimonides especially in regards to his Mishneh Torah. While the influence of Muslim thought on Maimonides's philosophy has been the frequent subject of academic studies, that the influence can also be seen in other significant areas of Maimonides's work helps support Stroumsa's argument, on the one hand, but more importantly offers new directions for future study. Chapter 4, "La Longue Durée: Maimonides as a Phenomenologist of Religion," explores the place of the Sabians in Maimonides's understanding of the role of the Sabians in Maimonides explanation of the biblical commandments. The chapter begins by constructing a picture of the Sabians as they appeared in the Arabic literature known in Maimonides's time. Stroumsa then discusses how Maimonides used the pagan practices attributed to this ancient people to explain the development of biblical monotheism.

Chapter 5, "A Critical Mind: Maimonides as Scientist" offers an exposition on the meaning of the term hadhayān (ravings) in Maimonides's scientific works. Here Stroumsa concludes that "Its use indicates that Maimonides regards the theory under discussion as related in some way to the esoteric non-Aristotelian philosophies of his times, and in particular to their irrational, mythical discourse and to the sciences of the occult. By describing them as "ravings" he intends to underline their false pretense to be scientific knowledge." (p. 152) In Chapter 6, "'From Moses to Moses': Maimonides' Vision of Perfection," Stroumsa explores the tension between Maimonides' responsibility to "perfect" the Jewish community and his desire for "individual salvation." The exploration largely relies on paralleling Maimonides's thought with that of Avicenna.

Without doubt, the reader of Maimonides and His World will benefit from Stroumsa's very close reading of select texts and her broad knowledge of Arabic literature, and Muslim thought, theology, and philosophy. Importantly, the book serves as a corrective to scholars who have preferred to examine Maimonides as a Jewish thinker in dialogue with his Jewish predecessors and scholars of the medieval Muslim world who rarely investigate him in a sustained way to ask what his life and learning might contribute to the understanding of the world in which he lived.

The book not only raises questions about the direction of Maimonides-related scholarship but of academia more broadly. Stroumsa challenges contemporary scholars' dismissal of the category of "Mediterranean" as well as the move away from exploring the influences which shaped an individual's thinking.

Finally, the book's conclusion is worthy of note for more than its summary of Stroumsa's argument. Throughout the volume Stroumsa returns to the work of her Hebrew University 
teacher, Shlomo Pines, who promoted the approach she propounds in the book. She has argued elsewhere ("Shlomo Pines: le savant, le sage," Journal Asiatique 278, nos. 3-4, 1990) that his approach was not followed by subsequent generations of scholars and that they, like her Hebrew University colleague Eliezer Schweid whom she criticizes explicitly, see "the Islamic world provid[ing] only the background to Jewish philosophy." (p. 189) As rector of the Hebrew University, Stroumsa may not only be laying out new directions for the study of Maimonides in this volume, but a critique of the direction of the scholarship of "Jewish Thought" at her own institution.

Additionally, given her position as an Israeli academic, it seems Stroumsa has found in Maimonides's Mediterranean a worthwhile model which may define a place for the university in promoting peace in the Middle East:

Maimonides' erudition in subjects that are not typically Jewish could not have been achieved in a rarified Jewish environment, without extensive, personal contacts with the non-Jewish world. It is from Muslims, as well as from Jews, that he bought and borrowed books, and also with Muslims that he discussed and debated ideas. The snippets of information provided by Muslim biographers as well as by Maimonides himself corroborate the existence of such extensive contacts. If we assume that Maimonides met Muslim thinkers, and exchanged with them knowledge and ideas, by the same token we must assume that Muslim thinkers met with Maimonides, and exchanged with him knowledge and ideas. (p. 191)

For the important implications of her work for Maimonides studies and for this broader concern the reader of this fine volume owes Stroumsa a debt of gratitude. 